\title{
MEETING WITH MCTIC AND ANATEL
}

\section{Chair: Tereza Mondino - Diretora da TM Consultoria em Telecomunicações}

The panel will update the information on the regulatory actions of MCTIC and ANATEL, concluded and planned, promoting a discussion about its adequacy to the needs and expectations of the Broadcasting sector.

- FUTURE PERSPECTIVES ON THE REGULATORY ACTIVITIES OF ANATEL

Speaker : Vitor Elísio Góes de Oliveira Menezes - Superintendente de Outorga e Recursos à Prestação da ANATEL

- THE CHALLENGES OF OPEN TV FACING DIGITAL TRANSITION AND MULTIPLATFORM SCENARIO

Speaker: Ivan Miranda - Director of Engineering at GRPCOM / RPCTV (Globo TV Affiliate in Paraná) and member of the Executive Board of SET as a director for the Southern Region.

We will address the importance of Open TV to Brazil, given its importance in a country with continental dimensions, emphasizing its role as the main instrument of social inclusion, in the face of the digitization process and the multiplatform scenario. Open TV in Brazil has unique characteristics in the world, since its capillarity and penetration in a country of continental dimensions, playing an important role of social inclusion since its reach of more than $97 \%$ of the population. With the process of digitization and availability of content on several platforms, Open TV has been reinventing itself, but its foundations continue to be based on services originally of broadcasting. In order to give the necessary speed, close participation of MCTIC and ANATEL is necessary, working in perfect synergy with the industry, in a common interest, that is, of the population. In this way, we will counterbalance the current reality of the Sector versus its needs, discussing how legislation can be updated to give the necessary speed to broadcasting. 


\title{
- DEREGULATION OF THE BROADCASTING SECTOR AND NEW PERSPECTIVES.
}

\author{
Speaker: Vanda Bonna - Secretária de Radiodifusão do MCTIC
}

\section{- Speaker: Samir Nobre - Diretor de Radiodifusão Educativa, Comunitária e de Fiscalização do MCTIC}
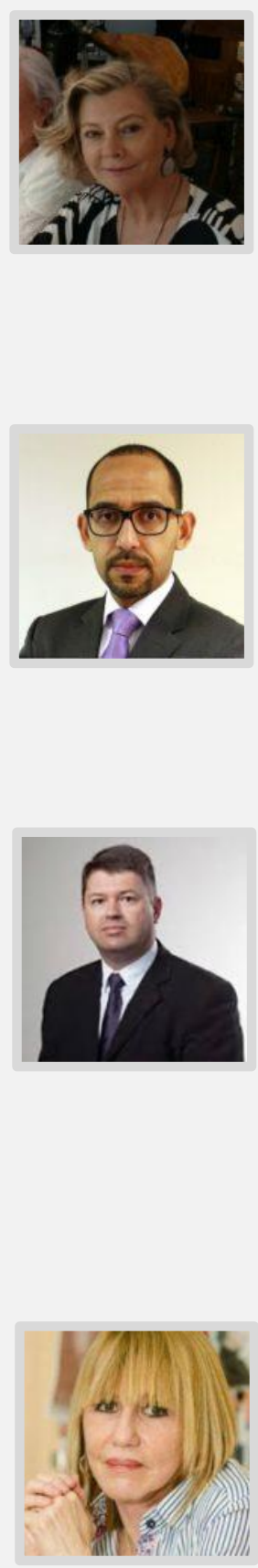

Tereza Mondino - Diretora da TM Consultoria em Telecomunicações

Consultant to SET from 1999 to 2003 and again since 2006, being involved in regulatory affairs and digital TV planning. She graduated in Electrical Engineering (Electronics option) from UnB, in 1974. She served at the Ministry of Communications until 1998, working in the Broadcasting and Pay TV - Cable TV, MMDS and DTH areas in drafting regulations, technical standards and in planning. She took part in the broadcasting commissions of MERCOSUR, CITEL and ITU.

Vitor Elísio Góes de Oliveira Menezes - Superintendente de Outorga e Recursos à Prestação da ANATEL

Is a lawyer specializing in Administrative Law, Public Management and the Regulation of Public Telecommunications Services; he has been a career civil servant at Anatel since 2007, having spent time at the Superintendence for Private Services, Legal Counsel to the President of Anatel and currently holds the position of Superintendent for Concessions and Provision of Resources.

Ivan Miranda - Director of Engineering at GRPCOM / RPCTV (Globo TV Affiliate in Paraná) and member of the Executive Board of SET as a director for the Southern Region.

He holds a degree in Electrical Engineering, specializing in Telecommunications. He holds a graduate degree in Enterprise Management from the Getúlio Vargas Foundation - FGV and Program for Management Development from the University of Navarra. He is in charge of implementing digital TV transmissions at the 8 television stations of RPCTV in the state of Paraná, the migration of RPCTV journalism to the HD format, setting up the HD View production unit (truck for covering events) and the implementation of OTV (subscriber TV station).

Vanda Bonna - Secretária de Radiodifusão do MCTIC

Lawyer, Professor of Broadcasting Legislation by SENAC / DF and has held the positions of Head of Legal Affairs of the Dentel Supervision; Coordinator of Supervision of the SNC; General Coordinator of MTC's Regional Supervision and Supervision; Deputy Director of the Department of Communications Supervision; Chairman of the Board of TELASA; Member of the Board of Directors of TELEPARÁ and currently holds the position of Secretary of Broadcasting. 


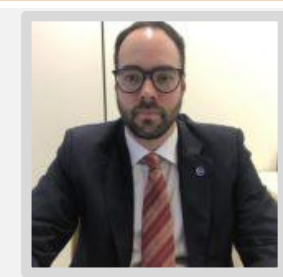

Samir Nobre - Diretor de Radiodifusão Educativa, Comunitária e de Fiscalização do MCTIC Lawyer, has held the positions of Assistant of the Department of Commercial Broadcasting, Coordinator of Corporate Acts; General Coordinator of Inspection; General Coordinator of Community Broadcasting; General Coordinator of Commercial Broadcasting; Chairman of the Broadcasting Bidding Commission; General Coordinator of Educational Broadcasting and Consignations of the Union and currently holds the position of Director of the Department of Educational, Community and Supervision Broadcasting. 